\title{
The Effects of Work Exclusion on Work Alienation and Collegaue Support on Private Sport Enterprises Trainers
}

\section{Research Article}

\section{Suzan DAL ${ }^{1}$, Nedim MALKOC ${ }^{2}$}

${ }^{1}$ Istanbul University, Faculty of Sport Sciences, Department of Sport Management, Istanbul, Turkey, ORCID: 0000- 0002-7732-9846

${ }^{2}$ University, Faculty of Sport Sciences, Department of Sport Management, Istanbul, Turkey, ORCID: 0000-0003-4599-3547

To cite this article: Dal, S., \& Malkoc, N. (2020). The Effects of Work Exclusion on Work Alienation and Collegaue Support on Private Sport Enterprises Trainers, International Online Journal of Educational Sciences, 12(3), 288-297.

\section{ARTICLE INFO \\ Article History:}

Received: 21.12.2019

Available online:

23.07.2020

\begin{abstract}
This study is carried out to examine the effect of organizational exclusion on work alienation and the support of colleagues trainers working in private sports enterprises. The sample of the research consists of 183 trainers, 21 of whom are women and 162 of whom are men working in private sports enterprises. Data were collected by way of "Personal Information Form, Organizational Exclusion, Work Alienation and Colleague Support Scales", while frequency, correlation and regression analysis were used to analyze the data that were obtained. Results show that the organizational exclusion of trainer in private sports enterprises. Organizational exclusionhas a positive effect on work alienation, and a negative effect on the support of colleagues. Therefore, it could be deduced that organizational exclusion is a strong determinant of work alienation and the colleagues support on trainers.
\end{abstract}

(C) 2020 IOJES. All rights reserved

Keywords:

Organizational Exclusion, Work Alienation, Trainers, Colleague Support, Private Sports Enterprises

\section{Introduction}

It has been observed that the ability of organizations to maintain their presence more strongly depends on the ability to use their resources effectively and efficiently, in an increasingly competitive environment. One of the most important and variable resources they have is employees. Employees are the primary factors affecting success (Naktiyok and Karabey 2007, 204). However, the ability of employees to perform well and to work efficiently is affected by many variables inside and outside of the organization. An organization's ability to meet the needs and expectations of its employees, and employees' ability to feel the support of the

\footnotetext{
${ }^{1}$ Corresponding author's address: Istanbul Üniversitesi Spor Bilimleri Fakültesi Spor Yöneticiliği Bölümi

Telephone: +905545893498

e-mail: suzann.dal@gmail.com

DOI: https://doi.org/10.15345/iojes.2020.03.020
} 
organization and of other employees on certain issues have affected the performance of various enterprises (Nergiz and Yılmaz, 20169).

Organizational exclusion is defined as ignoring individuals in the workplace by other employees (Zhao et al., 2013: 220). In this respect, exclusion or exclusion activities within the organization affect many organizational behavior issues. Colleague support includes interaction with other individuals at the same organization level (Mossholder et al., 2005: 609). In order to prevent organizational exclusion, it is possible to think that providing colleagues' support will positively affect this situation. Individuals' perceptions of support from their colleagues are reflected in work-related behaviors, as colleagues' support reduces the individuals' withdrawal and withdrawal behaviors in particular (Mossholder et al., 2005:609). Work alienation can be considered as one of the consequences of work-related negative behavior of organizational exclusion. In this respect, organizations and individuals have a positive role to play in eliminating the sense of alienation (Mohan and Prasad, 2014:242). The positive support effect of friend support can be achieved through alienation to the job. In this context, the success of an organization can be hinged on the minimum level of alienation and organizational exclusion tendencies and the high maintenance of colleagues' support.

The fact that there are many variables that affect the levels of organizational exclusion, job alienation and friend support show that these issues should be handled with so much care. Consequently, the effect of perceived organizational exclusion on work alienation and colleagues support was examined in this study.

Organizational exclusion, is an issue studied in many fields and expressed in different terms. These terms can be defined as the personal perceptions of employees who are ignored by their employers or ignored by their colleagues, such as exclusion, cold standing, expulsion, unawareness, ignorance and exile(Williams, 2007; Williams, 2009; Williams, et al. 2000; Prinstein, Aikins, 2004; Yang, 2012; Williams and gerber, 2005; Hitlan et al. 2006: 217; Leung et al., 2011). More clearly, it is also defined as being excluded, hindered or ignored by others so that individuals are not allowed to establish positive relationships, succeed and gain respect in their workplaces (Hitlan et al., 2006: 217). Exclusion, which is used to express behaviors such as being ignored and excluded, threatens an individual's basic sense of belonging and leads to various damaging effects on the social and mental functions (Williams, 2007, Zadro et al., 2006; Yang, 2012). Workplace is one of the most important social environments in which exclusion is experienced and it is considered as a stress factor associated with working life (Fox and Stallworth, 2005; Haq, 2014; Wu vd., 2012:182). In this regard, the phenomenon of exclusion, which is frequently encountered in the working environment ( $\mathrm{Wu}$ et al., 2011: 24), creates significant negative effects on both the organization and the employees (Willams and Nida, 2011: 73, Wu et al., 2011: 24; Hitlan et al., 2015: 2).

Work alienation, the concept of alienation as it is often used in contemporary sociology is based upon a philosophical-religious origin (Tolan, 1980:175-178). According to Hegel (1991), who was the first to use the concept of alienation, alienation is the result of the distinction between the physical and spiritual existence of man. The concept was embodied by K. Marx, and started to be used as an assumption of human life (Hilav, 1995:44-45). The concept of work alienation is based on the work of Karl Marx. In Marx's (1993) manuscript named '1844 Elyazmaları', alienation was discussed as "the restriction of man's creativity" and "the compulsion to produce objects of no importance or meaning to himself and to convert freely created objects into marketable goods" (Çelik, 2011: 16). According to Marx, alienation from work is the separation of the worker from the product in which he/she is involved in the production process or from the people involved in the process of production and consumption (Nair and Vohra, 2010).

When we look at the definitions of alienation outside of Marx's, we will see a working condition that deprives the individual from exercising control over the production processes, interaction with colleagues and customers, and the individual's abilities (Kanungo, 1992:416). The alienation of an employee at work occurs as a result of the conflict between roles required by the organization and the employee's own nature 
(Mottaz, 1981: 515). Blauner (1964) describes work alienation as a condition which results from a "failure to provide working conditions and conduicive environments capable of demonstrating the individual's value as a human being, such as autonomy, responsibility, social interaction and self-actualization". Blauner (1964) and Seeman (1959) approached the phenomenon of alienation from a socio-psychological perspective rather than from a structural perspective, as opposed to by the Marxist approach. In particular, the perception of work considered as meaningless by the employee is regarded as a determining factor in alienating someone at the workplace (Mottaz, 1981: 517). Halbesleben and Clark (2010) describe work alienation as an alienation from others and as a distance between employees and other employees.

Work alienation is a common phenomenon in post-industrial society and organizations and organisations in both the private and public sectors are constantly struggling with how to handdle the phenomenon of alienation so as to be able to continue their operations (Kanungo,1992:414). Work alienation has both personal and social dimensions to it. Personal alienation refers to an individual's daily work attitude and how he/she alienateshimself or herself. However, social alienation refers to the inability to interact with others which leads to loneliness (Korman et. al. 1981:344). Alienation can negatively affect the health and performance of an employee, cause psychosomatic illness and reduce the employee's productivity (Mohan and Prasad, 2014: 142).

From studies conducted in this subject area, it is was observed that work alienation phenomenon in organizations is of great importance for both the organization, the employer and the employee. In this regard, work alienation is an important issue for both the organization and the employees in terms of having negative effects on the general health of the employees, work performance, attendance, work satisfaction, productivity and commitment to the organization (Uğur ve Erol 2015). For this reason, it creates negative effects on employees and the organization as a result of alienation. In order to minimize the individual and organizational effects of alienation, its management is essential for both employees and organizations.

The support of colleagues, comes from social support theory (Mossholder et al., 2005:609). By associating with social support, colleague support can be explained with the intention of helping and helping others in the workplace (Harris et al., 2007:150). The perception people have that they are supported by others in every area of their lives makes them feel good. Accordingly, it is an important issue for the person to feel supported at work as an employee (Giray ve Şahin 2012). The reason for this is that the employee needs to be accepted and supported by the colleagues with whom he/she spends time and shares his/her feelings. (Rhoades ve Eisenberger, 2002). Colleague support is a concept that enables those working in an organization to work in cooperation and solidarity by helping each other(Demirer, 2017; 1049). Colleague support includes interaction with other individuals at the same organization level (Mossholder et al., 2005: 609).

Studies revealed the relationship of colleagues' support to variables related to work and organization such as job satisfaction, emotional commitment and intention to quit(Ng and Sorenson, 2008). In addition, the support of colleagues was found to be a factor affecting job satisfaction, depression level, burnout level, withdrawal and leaving the workplace, work status, work performance and work satisfaction (Mossholder et al., 2005; Leiter and Maslach, 1988; Stice et al., 2004; Soyer and Can, 2007; Beehr et al., 2000; Babin and Boles, 1996; AbuAlRub, 2006).

The fact that there are so many variables that affect the levels of organizational exclusion, job alienation and colleague support suggests that these issues need to be handled in detail. Thus, the effect of perceived organizational exclusion on work alienation and colleague support was examined in this study, especially in the sports industry. However, limited studies on the understanding and explaining of employees' behaviors will make it easier to predict the future situations of employees' behaviors that are very difficult to determine through these studies. Therefore, the hypotheses created from this point of view are: 
- H1: Organizational exclusion has a significant positive effect on work alienation.

- H2: Organizational exclusion has a significant negative effect on perceived colleague support.

\section{Method}

\section{Participants}

Relational screening model was used in this study, and the sample of the study consists of 183 trainers working in İstanbul private sports enterprises. The data were collected by simple random sampling method. A total of 183 trainers, $11.5 \%(n=21)$ women and $88.5 \%(n=162)$ men, participated in the study.

\section{Data Collecting Tools}

Since this is a quantitative study, organizational exclusion, work alienation and colleague support scales were used as data collection tools.

Personal Information Form: This form includes age, gender, marital status and educational status questions created by researchers to learn about the demographic information of employees.

Organizational exclusion scale: A validity reliability study of the scale was conducted by Abasli and Özdemir (2019). The scale consists of 14 items. It has two sub-dimensions: alienation and nullization. The first five items measured isolation and the other items measured slightness. The Cronbach alpha internal consistency coefficient of isolation is.88 while the nothingness coefficient is.96 and the total Cronbach alpha internal consistency coefficient of the scale is .97 and was determined as $\alpha=0.973$.

Work alienation scale: The scale used to determine the level of alienation of the employees was developed by Hirschfeld and Field (2000), and the validity-reliability study was carried out by Özbek (2011). The work alienation scale includes one-dimension consisting of 10 items under the name of work alienation. The scale is a five-point likert type, and the internal consistency regarding the work alienation scale was calculated as $\alpha=$ 0.789 .

Colleagues support scale: The scale of perceived colleagues support was developed by Giray and Sahin (2012). The Cronbach Alpha internal consistency coefficient of the scale is 0.90 and the scale is a five-point likert type. The internal consistency of the scale was found to be $\alpha=0.876$. The scale is one-dimensional and it consists of 10 items.

\section{Results}

Demographic information about the participants was presented in Table 1 below.

Table 1. Demographic information of the participants

\begin{tabular}{llcc}
\hline \multirow{2}{*}{ Gender } & Fariables & Number & Percentage \\
\hline & Male & 21 & 11,5 \\
\cline { 2 - 4 } & Total & 162 & 88,5 \\
\hline \multirow{3}{*}{ Marital Status } & Single & 183 & 100,0 \\
\cline { 2 - 4 } & Married & 63 & 34,4 \\
\cline { 2 - 4 } & Total & 120 & 65,6 \\
\hline \multirow{3}{*}{ Education Status } & High School & 25 & 100,0 \\
\cline { 2 - 4 } & Undergraduate- & 131 & 77,0 \\
\hline
\end{tabular}




\begin{tabular}{|c|c|c|c|}
\hline & Post-Graduate & 17 & 9,3 \\
\hline & Total & 183 & 100,0 \\
\hline \multirow{6}{*}{ Age } & $22-26$ & 43 & 23,5 \\
\hline & $27-31$ & 49 & 26,8 \\
\hline & $32-36$ & 50 & 27,3 \\
\hline & $37-41$ & 26 & 14,2 \\
\hline & 42 and over & 15 & 8,2 \\
\hline & Total & 183 & 100,0 \\
\hline \multirow{4}{*}{$\begin{array}{l}\text { Working Time in the } \\
\text { Institution }\end{array}$} & 1 year and under & 47 & 25,7 \\
\hline & 1 year -5 year & 116 & 63,4 \\
\hline & 5 year and over & 20 & 10,9 \\
\hline & Total & 183 & 100,0 \\
\hline \multirow{4}{*}{$\begin{array}{l}\text { Working Time in the } \\
\text { Profession }\end{array}$} & 1 year and under & 22 & 12,0 \\
\hline & 1 year- 5 year & 68 & 37,2 \\
\hline & 5 year and over & 93 & 50,8 \\
\hline & Total & 183 & 100,0 \\
\hline
\end{tabular}

$11.5 \%(n=21)$ of the participants were female and $88.5 \%$ were male $(n=162)$, and a total of 183 people participated in the study. $34.4 \%(\mathrm{n}=63)$ of the participants were single and $65.6 \%(\mathrm{n}=120)$ were married.13.7\% of employees $(n=25)$ have High School, 77\% ( $n=141)$ Undergraduate -Graduate and 9.3\% (n=17) have postgraduate education level.

The age range of the participants was as follows; $23.5 \%(n=43)$ of them were $22-26$ years old, $26.8 \%(n=49)$ of them were 27-31 years old, $27.3 \%(\mathrm{~N}=50)$ of them were $32-36$ years old, $14.2 \%(n=26)$ of them were $37-41$ years old and $8.2 \%(n=15)$ of them were 42 and over. The duration for working in the institution was as follows; $25.7 \%$ of the participants $(n=47)$ have worked 1 year and below, $63.4 \%(n=116)$ of them have worked 1 year5 years and $10.9 \%(n=20)$ of them have worked 5 years and above.

Table 2. Correlation Analysis

\begin{tabular}{|c|c|c|c|c|c|c|}
\hline & & 1 & 2 & 3 & 4 & 5 \\
\hline 1 & Work alienation & 1 & & & & \\
\hline 2 & Colleagues' Support &,$- 350^{*}$ & 1 & & & \\
\hline 3 & Isolation & $451^{*}$ &,$- 311^{*}$ & 1 & & \\
\hline 4 & Slightness &, $506^{*}$ &,$- 381^{*}$ & $900^{*}$ & 1 & \\
\hline 5 & $\begin{array}{l}\text { Organizational Exclusion } \\
\text { (Total) }\end{array}$ & $498^{*}$ &,$- 364^{*}$ &, $958^{*}$ & $987^{*}$ & 1 \\
\hline
\end{tabular}

${ }^{*} \mathrm{p}<.01, \mathrm{~N}$ : 183, r: Pearson correlation coefficient

The relationship between the subscale scores of work alienation scale, the colleagues support scale and the organizational exclusion scale was determined by pearson product-moment correlation analysis. According to the results of the analysis; work alienation scores were found to be statistically significant and positively related to the total scores of organizational exclusion $(r=.498, p<.01)$ and the subscales of organizational exclusion scale in which isolation scores were $(\mathrm{r}=.451, p<.01)$ and slightness scores were $(\mathrm{r}=.506$, $p<.01)$. In contrast, work alienation scores was found to be statistically significant and negatively related with colleagues support scale $(r=-.350, p<.01)$. Furthermore, the colleagues support scale scores were found to be significantly and negatively low when associated with the total scores of organizational exclusion ( $r=-.364$, 
$p<.01)$ and the subscales of organizational exclusion scale in which isolation scores were $(r=-.311, p<.01)$ and slightness scores were $(\mathrm{r}=-.381, p<.01)$.

Table 3. Regression analysis on the prediction of organizational exclusion by colleagues' support and alienation to work.

\begin{tabular}{lcccc}
\hline & $\boldsymbol{B}$ & $\boldsymbol{\beta}$ & $\boldsymbol{t}$ & $\boldsymbol{p}$ \\
\hline Constant & 1,848 & & 4,627 &, 000 \\
\hline Work alienation &, 439 &, 422 & 6,286 &, 000 \\
\hline Colleagues' Support &,- 293 &,- 217 & $-3,229$ &, 001 \\
\hline
\end{tabular}

$\mathrm{R}=.538 \mathrm{R} 2=.289 \mathrm{R} 2 \mathrm{adj}=.281, \mathrm{~F}(2,180)=36.572, \mathrm{p}<.01$

Dependent Variable: Organizational Exclusion (Total)

In order to examine whether the work alienation scale and colleague support scores predicted the total scores of the organizational exclusion scale, the work alienation scale and colleague support scores were determined as independent variable and total scores of the organizational exclusion scale were determined as dependent variable and then the standard multiple regression analysis was carried out. It was determined that the simple linear regression model, in which all independent variables were included in the equation (Enter), significantly predicted the organizational exclusion total scores $[\mathrm{F}(2,180)=36.572, p<.01]$. The model describes $29 \%$ of the variance in total scores of organizational exclusion $\left(R^{2}=.289\right)$. Standardized regression coefficients revealed that work alienation scores significantly and positively predict the total scores of organizational exclusion $(\beta=.422, p<.01)$ whereas, colleague support scores significantly and negatively predict the total scores of the organizational exclusion $(\beta=-.217, p<.01)$.

\section{Discussion and Conclusion}

It is important to prevent development of negative attitudes and behaviors in organizations consisting of human relations such as sports. Therefore, it is essential for both individuals and organizations to prevent the development of negative attitudes and behaviors in organizations and to create environments that will lead to positive attitudes and behaviors, and to develop the necessary methods. The research was carried out on 183 trainers (21 Women, 162 Men) working in private sports enterprises. 34.4\% ( $\mathrm{n}=63$ ) of the participants were single and $65.6 \%(n=120)$ were married. $13.7 \%$ of employees $(n=25)$ have High School, $77 \%(n=141)$ Underdraduate-Graduate and 9.3\% ( $n=17)$ have post-graduate education level. The age range of the participants was as follows; $23.5 \%(n=43)$ of them were 22-26 years old, $26.8 \%(n=49)$ of them were 27-31 years old, $27.3 \%(\mathrm{~N}=50)$ of them were $32-36$ years old, $14.2 \%(n=26)$ of them were $37-41$ years old and $8.2 \%(n=15)$ of them were 42 and over. The duration for working in the institution was as follows; $25.7 \%$ of the participants $(\mathrm{n}=47)$ have worked 1 year and below, 63.4\% $(\mathrm{n}=116)$ of them have worked 1 year- 5 years and $10.9 \%(n=$ 20) of them have worked 5 years and above.

According to the results of the analysis, work alienation was found to be positively related to the total scores of organizational exclusion and the subscales of organizational exclusion scale in which isolation scores and nothingness scores. When one of these variables increases or decreases, the other variable is expected to increase or decrease. And to be precise, organizational exclusion is associated with the alienation of employees to work.

There are limited number of similar studies in the literature on organizational exclusion, work alienation and colleague support among the available sources.

A study by abasli (2018) on teachers' views concluded that, as the level of organizational exclusion perception of teachers increases, their perception of alienation to work also increases. Exclusion or exclusion activities within the organization affect many organizational behavior issues (Soybalı and Pelit, 2019). In the case of organizational exclusion, it has been determined that there is a positive association with intention to 
leave work, exhibit anti-productivity behaviors, decline in service performance, emotional exhaustion, exhibition of depressed mood, and work stress (Haq, 2014:1309, Zhao et al. 2013:224, Leung et al., 2011:836, Wu et al., 2012:178).

Considering the studies on organizational mobbing, which is one of the most important factors affecting organizational alienation: Zengin and Kaygin (2016) found that mobbing is effective in organizational alienation. Soybalı and Pelit (2019) detected the positive relationship between organizational exclusion and organizational cynicism. In addition, a negative relationship was observed between organizational cynicism and organizational commitment with a similar relationship(Malkoç and Sunay, 2020). Lyu, and Zhu, (2019) observed that organizational exclusion reduces dedication and emotional commitment to work, induces intention to quit work, and reduces intrinsic motivation.

The current study reveals that there is a significant negative relationship between work alienation and colleague support. Thus, it is deduced that the level of alienation of the employees decrease when they feel the support of their colleagues

One of the similar studies conducted by Taştan et al. (2014) revealed that the perception of organizational support, which also includes the support of colleagues, negatively affects work alienation. Additionally, as a result of the researches of Kılıç (2016) and Günay (2017), a significant negative relationship was found between organizational alienation and the perception of organizational support.

When the organizational behavior issues influenced by the support of colleagues were examined, it was observed that if an employee is not supported by his/her colleagues, there will be a decrease in commitment to work and the service performance of the person will decrease as he/she starts to exhibit negative social behaviors (Balliet \& Ferris 2013:298). In the study conducted by Avci (2017) on the employees of the hotel enterprises, it was stated that the quality and welfare of the employees were affected by the support of their colleagues.

According to the standard multiple regression analysis model which was performed to examine whether organizational exclusion predicted the work alienation scale and colleague support, It was determined that total scores of organizational exclusion were significantly predicted. The model describes $29 \%$ of the variance in total scores of organizational exclusion. Standardized regression coefficients revealed that work alienation scores significantly and positively predict the total scores of organizational exclusion $(\beta=.422$, $\mathrm{p}<.01)$ whereas, colleague support scores significantly and negatively predict the total scores of organizational exclusion $(\beta=-.217, \mathrm{p}<.01)$.

The results showed that organizational exclusion of trainers (21 Women, 162 Men) working in private sports enterprises had a positive effect on the work alienation, and a negative effect on the support of the colleagues. Based on the results, the current study supports the proposition that "organizational exclusion can be a strong determinant of work alienation and colleague support".

This study shows that job alienation and colleague support affect the organizational exclusion of those working in the private sports enterprises. However, in future studies, it is believed that conducting researches on other concepts that affect organizational exclusion will develop a perspective for a better understanding of the subject. The limitation arising from the fact that the study is carried out only on the employees working in the private sports enterprises can be eliminated by performing the study in different sectors and different institutions in subsequent studies. 


\section{REFERENCES}

Abasl1, K. 2018. Teachers' opinions on the relationship among organizational ostracism, work alienation and organızatıonal cynicism. (Doctoral dissertation) Hacettepe University, Department of Education Sciences, Education Management Inspection Planning and Economics Program

Abu Al Rub, R. F. 2006. Replication and examination of research data on job stress and coworker social support with internet and traditional samples. Journal of Nursing Scholarship, 38, 200-204.

Avci, N. 2017. The relationship between coworker supports, quality of work life and wellbeing: An empirical study of hotel employees. International Journal of Management Economics and Business, 13(3), 577-590. http://dx.doi. org/10.17130/ijmeb.2017331328

Babin, B. J. \& Boles, J. S. 1996. The effects of perceived coworker involvement and supervisor support on service provider role stress, performance and job satisfaction. Journal of Retailing, 72, 57-75.

Balliet, D., \& Ferris, D. L. 2013. Ostracism and prosocial behavior: A social dilemma perspective. Organizational Behavior and Human Decision Processes, 120 (2), 298-308. DOI: 10.1016/j.obhdp.2012.04.004.

Beehr, T. A., Jex, S. M., Stacy, B. A. \& Murray, M. A. 2000. Work stressors and coworker support as predictors of individual strain and job performance. Journal of Organizational Behavior, 21, 391-405.

Blauner, R. 1964, Alienation E Freedom: The Factory Worker And Hiois Industry, The University of Chicago Press, Lrd., London, The United States of America.

Çalışkan, A., Pekkan, N. Ü. 2017. Psikolojik sermayenin işe yabancılaşmaya etkisinde örgütsel desteğin aracılık rolü. İş ve İnsan Dergisi, 4(1), 17-33.

Çelik, N. B. 2011 “marx mı dünyaya, dünya mı marx’a yabancılaştı”, Doğu Batı Dergisi, 55: 11-31.

Demir, M., Ayas, S., Yıldız, B., 2018, Örgütsel sinizm ve işe yabancılaşma ilişkisi: beş yıldızlı otel çalışanları üzerine bir araştırma. Journal of Administrative Sciences 16 (32), 231-254-

Demirer Cindiloğlu, M. 2017. Örgütlerde destek algılarının çalışanın duygularını ifade etmesi üzerine etkisi, Hitit Üniversitesi Sosyal Bilimler Enstitüsü Dergisi, 10(2), 1043-1060.

Fox, S., \& Stallworth, L. E. 2005. Racial/ethnic bullying: Exploring links between bullying and racism in the US workplace. Journal of Vocational Behavior, 66(3), 438-456.

Giray, M. D. \& Şahin, D. N. 2012. Algılanan Örgütsel, yönetici ve çalışma arkadaşları desteği ölçekleri: gecerlilik ve guvenirlirlik çalışması. Türk Psikoloji Yazıları, 15 (30), 1-9.

Günay, G. Y. 2017. The relationship among perceived organizational support, job satisfaction, and alienation: an empirical study on academicians. International Journal of Business and Social Science, 8 (1), 96-106.

Harris, J. I., Winskowskı, A. M. \& Brian E. E. 2007, Types of workplace social support in the prediction of job satisfaction, The Career Development Quarterly, 56, 151-156.

Haq, İ. U. 2014. Workplace ostracism and job outcomes: Moderating effects of psychological capital. Management, Knowledge and Learning International Conference, Slovenya, 1309-1323.

Hilav, S., 1995, Felsefe Yazıları, Yapı Kredi Yayınları, 2.Baskı, İstanbul.

Hitlan, R. T., Cliffton, R. J. \& DeSoto, M. C. 2006. Perceived exclusion in the workplace: the moderating effects of gender on work-related attitudes and psychological health, North American Journal of Psychology, 8 (2), 217-236.

Hitlan, R. T., Zarate, M. A.,. Kelly, K. M. \& DeSoto, M. C. 2015. Linguistic ostracism causes prejudice: support for a serial mediation effect. The Journal of Social Psychology. 1-15.

Halbesleben, J. R., Clark, S. K. 2010. The Experience of Alienation Among Temporary Workers in High-Skill Jobs: A Qualitative Analysis of Temporary Firefighters. Journal of Managerial Issues, 22(4), 531-545.

Kanungo, R. N.1992, Alienation and empowerment: some ethical imperatives. Business Journal of Business Ethics, 11, 413-422

Korman, A.K., Wittig Berman, U., Lang, D. 1981, Career success and personal failure: alienation among professionals and managers, Academy of Management Journal, 24(2), 342-360. Doi: 10.2307/255846 
Leiter, M.P. \& Maslach, C. 1988, The impact of interpersonal environment on burnout and organizational commitment. Journal of Organizational Behavior, 9, 297-308.

Leung, A. S. M., Wu, L. Z., Chen, Y. Y., \& Young, M. N. 2011. The impact of workplace ostracism in service Organizations. International Journal of Hospitality Management, 30(4), 836-844.

Lyu, Y., \& Zhu, H. 2019. The predictive effects of workplace ostracism on employee attitudes: A job embeddedness perspective. Journal of Business Ethics, 158(4), 1083-1095

Mohan, K.Chithra \& Prasad, P.N.2014, Work Alienation Among The Employees in It Sector, Paripex- Indian Journal of Research, 3,(5), 140-142.

Mossholder, Kevin W., Settoon, Randall P., and Stephanie C. Henegan 2005. A relational perspective on turnover: examining structural, attitudinal and behavioral predictors, Academy of Management Journal, 48 (4), 607-618.

Mottaz, Clifford J.(1981), some determinants of work alienation, The Sociological Quarterly, 22, (4), 515-529

$\mathrm{Ng}, \mathrm{T}$. W. H. \& Sorenson, K. L., 2008. Toward a further understanding of the relationships between perceptions of support and work attitudes: A meta-analysis. Group and Organization Management, 33, 243-268.

Nair, N. \& Vohra, N. 2010. An exploration of factors predicting work alienation of knowledge workers, Management Decision, 48(4): 600- 615.

Naktiyok, A. \& C. N. Karabey, 2007. İşletmelerin Maddi Olmayan Kaynakları ve Çevresel Olumsuzluk Algıları İle Stratejik Yönelimleri Arasındaki İlişki, Ankara Üniversitesi SBF Dergisi, 62-4.

Nergiz, E. \& Yılmaz, F., 2016. Çalışanların iş tatmininin iş performanslarına etkisi: Atatürk hava limanı gümrüksüz satış işletmesi örneği, Kastamonu Üni. İlbf Dergisi, (14)4, 5079.

Malkoç, N., \& Sunay, H. 2020. Özel Spor İşletmelerinde Çalışan Personelin Örgütsel Sinizm ile Örgütsel Bağlılık Düzeyleri Arasındaki İlişkinin Değerlendirilmesi. Spor Bilimleri Araştırmaları Dergisi, 5(1), 6275.

Mottaz, Clifford J. 1981. Some determinants of work alienation, The Sociological Quarterly, 22, (4), 515-529.

Prinstein, M. J., Aikins, J. W. 2004. Cognitive moderators of the longitudinal association between peer rejection and adolescent depressive symptoms. J Abn Child Psycho. 32: 147-158

Rhoades, L. \& Eisenberger, R., 2002. Perceived organizational support: a review of the literature. Journal of Applied Psychology, 87, (4), 698-714.

Soybalı, H. H. Pelit,. O. 2019. Otel işgörenlerinin örgütsel dışlanma algılarının örgütsel sinizm düzeylerine etkisi: beş yıldızlı otel işletmelerinde bir araştırma, İşletme Araştırmaları Dergisi, 11 (2), 1225-1246.

Seeman, M., 1959. On the meaning of alienation, American Sociological Review, 24, (6), 783-791.

Soyer, F. \& Can, Y. 2007. İş tatmini ile mesleki beklenti ve mesleki destek algılaması arasındaki ilişki: beden eğitimi öğretmenleri üzerinde bir araştırma. Türkiye Sosyal Araştırmalar Dergisi, Yı1.11, Sayı.3, 23-36.

Stıce, E., Ragan, J., Randall, P. 2004. Prospective relations between social support and depression: differential direction of effects for parent and peer support?. Journal of Abnormal Psychology, 113, (1), 155-159.

Tanrıverdi, H., \& K1lıç, N. (2016). Algılanan örgütsel destek ve örgütsel yabancılaşma arasındaki ilişkinin incelenmesi. Hacettepe Üniversitesi, Sosyolojik Araştırmalar E-Dergisi, 1(1), 1-18.

Taştan, S., İşçi, E. ve Arslan B. 2014. Örgütsel destek algısının işe yabancılaşma ve örgütsel bağlılı̆̆a etkisinin incelenmesi: İstanbul özel hastanelerinde bir çalışma. Pamukkale Üniversitesi Sosyal Bilimler Enstitüsü Dergisi, 19, 121-138.

Tolan, B., 1980, Çağdaş Toplumun Bulanımı; Anomi ve Yabancılaşma, Ankara İktisadi ve Ticari İlimler Akademisi Yayınları No:132, Ankara

Uğur, A., Erol, Z., 2015, Örgütlerde kritik sorun kaynağı olarak işe yabancılaşma, yabancılaşma ve bürokrasi arasındaki ilişkiye yönelik kavramsal bir yaklaşım, Kastamonu Üniversitesi İktisadi ve İdari Bilimler Fakültesi Dergisi, 8.182-192

Zengin, Y., \& Kaygın, E. 2016. Mobbing'in örgütsel yabancilaşmaya etkisi: bankacilık sektörü üzerinde bir araştırma. In International Turgut Özal Congress on Business, Economics and Political Science, 2, 55-65 
Williams, K. D. 2009, Ostracism: A temporal need-threat model. In M. Zanna (eds.), Adv experiment soc psycho. 279-314. New York: Academic Press.

Williams, K. D., Cheung, C. K. T., Choi, W. 2000. Cyber ostracism: effects of being ignored over the Internet. J Pers Soc Psycho. 79, 748-762.

Williams, K. D., \& Gerber, J. 2005. Ostracism: The making of the ignored and excluded mind. Interaction Studies, $6(3), 359-374$

Williams, K. D. \& Nida, S. A. 2011. Ostracism: consequences and coping. Current Directions in Psychological Science, 20(2), 71-75.

Wu, L. Z., Yim, F. H. K., Kwan, H. K., \& Zhang, X. 2012. Coping with workplace ostracism: The roles of ingratiation and political skill in employee psychological distress. Journal of Management Studies, 49(1), 178-199.

Wu, L. Z., Wei, L. Q. \& Hui, C. 2011. Dispositional antecedents and consequences of workplace ostracism: an empirical examination. Frontiers of Business Research in China, 5 (1), 23-44.

Yang, J. 2012. Workplace ostracism and performance related outcomes: A process model incorporating social influence and social identity theories. Post graduate dissertation, State Universtiy of New York, USA.

Zadro, L., Boland, C., \& Richardson, R. 2006. How long does it last? The persistence of the effects of ostracism in the socially anxious. Journal of Experimental Social Psychology, 42, 692-697

Zhao, H., Peng, Z. \& Sheard, G. 2013. Workplace ostracism and hospitality employees' counterproductive work behaviors: the joint moderating effects of proactive personality and political skill, International Journal of Hospitality Management, 33, 219-227. 